\title{
Food selectivity of anaerobic protists and direct evidence for methane production using carbon from prey bacteria by endosymbiotic methanogen
}

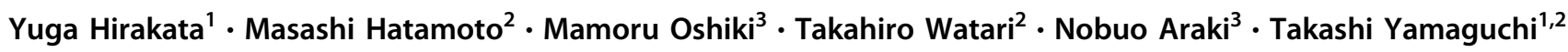

Received: 20 December 2019 / Revised: 5 April 2020 / Accepted: 7 April 2020 / Published online: 27 April 2020

(c) The Author(s), under exclusive licence to International Society for Microbial Ecology 2020

\begin{abstract}
Anaerobic protists are major predators of prokaryotes in anaerobic ecosystems. However, little is known about the predation behavior of anaerobic protists because almost none have been cultured. In particular, these characteristics of anaerobic protists in the phyla Metamonada and Cercozoa have not been reported previously. In this study, we isolated three anaerobic protists, Cyclidium sp., Trichomitus sp., and Paracercomonas sp., from anaerobic granular sludge in an up-flow anaerobic sludge blanket reactor used to treat domestic sewage. Ingestion and digestion of food bacteria by anaerobic protists with or without endosymbiotic methanogens were demonstrated using tracer experiments with green fluorescent protein and a stable carbon isotope. These tracer experiments also demonstrated that Cyclidium sp. supplied $\mathrm{CO}_{2}$ and hydrogen to endosymbiotic methanogens. While Cyclidium sp. and Trichomitus sp. ingested both Gram-negative and -positive bacteria, Paracercomonas sp. could only take up Gram-negative bacteria. Archaeal cells such as Methanobacterium beijingense and Methanospirillum hungatei did not support the growth of these protists. Metabolite patterns of all three protists differed and were influenced by food bacterial species. These reported growth rates, ingestion rates, food selectivity, and metabolite patterns provide important insights into the ecological roles of these protists in anaerobic ecosystems.
\end{abstract}

\section{Introduction}

Anaerobic protists are major predators of prokaryotes that affect the abundance, structure, and diversity of prokaryotic communities in various anaerobic environments such as lakes, groundwater, rumina, and bioreactors [1-6]. Bacterivorous protists have different hunting characteristics and species-specific prey preferences, and each of these protists has its own ecological niche [7-9]. Protist prey preferences

Supplementary information The online version of this article (https:// doi.org/10.1038/s41396-020-0660-0) contains supplementary material, which is available to authorized users.

Masashi Hatamoto

hatamoto@vos.nagaokaut.ac.jp

1 Department of Science of Technology Innovation, Nagaoka University of Technology, Nagaoka, Niigata, Japan

2 Department of Civil and Environmental Systems Engineering, Nagaoka University of Technology, Nagaoka, Niigata, Japan

3 Department of Civil Engineering, Nagaoka College, National Institute of Technology, Nagaoka, Niigata, Japan results in distinct responses in the composition of prokaryotic community such as disappearance of specific prokaryotes and dominance of bacteria that have resistant to predation (e.g., filamentous bacteria, microcolony-forming bacteria, and Gram-positive bacteria) [10]. On the other hand, some protist species can ingest grazing-resistant bacterial cells mentioned above [11, 12]. The prey preferences of protist against various prokaryotes cell type (shape, size, and cell-wall structure) are key factor to control prokaryotic community structures.

Many types of anaerobic protists such as amoeba, ciliates, and flagellates have been observed in anaerobic environments under a microscope [13-16] and predation by protists strongly affect bacterial and archaeal community structures in anaerobic ecosystems [17, 18], but few studies that focused on the predation behavior of and metabolites from these organisms though the aerobic protists are well studied. Among anaerobic protists, only Trimyema compressum has been investigated for its food selectivity $[19,20]$. These studies showed that $T$. compressum could ingest both bacteria and archaea, and that Gram-negative bacteria, specifically, supported its growth. However, food selectivity of other anaerobic protists remains largely 
unknown. In addition, molecular methods based on $18 \mathrm{~S}$ rRNA gene sequencing revealed that protist communities in anaerobic environments contain a substantial number of unknown species that are distantly related based on sequences available in genetic databases [21, 22]. Thus, because they have been overlooked and remain uncultured, the ecological roles of most anaerobic protists are poorly understood.

In wastewater treatment processes, anaerobic protists contribute to sludge reduction by predation, degrading particulate organic matter, including bacterial cells [23, 24]. Anaerobic protists produce various metabolites through fermentative metabolism of food bacteria, with major products that include ethanol, fatty acids, hydrogen, and carbon dioxide [25, 26]. Our previous study suggested that the supply of metabolites produced by anaerobic protists increased when they fed on anaerobic syntrophic bacteria that preferred fatty acids, resulting in high microbial diversity [1]. Thus, metabolites produced by anaerobic protists are important factors that shape microbial communities in anaerobic ecosystems.

In addition, some anaerobic protists harbor endosymbiotic methanogens in their cytoplasm [14, 27, 28]. Several reports have indicated that these endosymbiotic methanogens are closely associated with protist metabolism because they scavenge the hydrogen produced by host protists [29-31]. However, the metabolism of anaerobic protists, including endosymbiotic methanogens, have not yet been investigated. Stable isotope tracer techniques have been used to examine the decomposition pathways of certain substrates [32, 33]. However, although ${ }^{13} \mathrm{C}$ tracer techniques have been used to investigate the metabolism of parasitic protists [34, 35], no study has examined anaerobic protists with endosymbiotic methanogens in their cells.

In this study, we isolated anaerobic protists from anaerobic granular sludge in a domestic wastewater treatment plant to investigate the food selectivity of anaerobic protists with or without endosymbiotic methanogens. Further, we established monoxenic cultures of ciliate Cyclidium sp. strain YH (phylum Ciliophora) that harbor endosymbiotic methanogens, flagellate Trichomitus sp. strain YH (phylum Metamonada), and Paracercomonas sp. strain YH (phylum Cercozoa). Although, protists belonging to these three phyla were detected throughout the year in a UASB reactor used to treat domestic sewage [36], the food selectivity of and metabolites from these protists have not been investigated. In particular, these characteristics of anaerobic protists in the phyla Metamonada and Cercozoa have not been reported previously. Therefore, ingestion and digestion of bacteria by three protists and methane production by endosymbiotic methanogens were examined through a tracer experiment using green fluorescent protein (GFP) and stable isotope ${ }^{13} \mathrm{C}$. In addition, the effects of food bacteria on the growth, food selectivity, and metabolites of these protists were investigated through feeding experiments with various food bacteria.

\section{Materials and methods}

\section{Isolation and cultivation of protists}

Anaerobic granular sludge containing protist cells was obtained from the sampling port at the bottom of a UASB reactor at a domestic sewage treatment center in Nagaoka City, Japan [36]. These cells were cultured anoxically at room temperature $\left(25^{\circ} \mathrm{C}\right)$ in a ciliate mineral medium as described previously [27]. Escherichia coli strain K-12 was used as the food bacteria for cultivation. E. coli cells were grown overnight in M9 minimal medium [37] containing $10 \mathrm{mM}$ of glucose and $0.03 \%$ yeast extract at $37^{\circ} \mathrm{C}$ with shaking at $200 \mathrm{rpm}$. The cells were harvested by centrifugation at $8000 \mathrm{rpm}$, washed three times with $0.1 \mathrm{M}$ phosphate-buffered saline (PBS), and resuspended in the ciliate mineral medium. Stigmasterol and ergosterol dissolved in ethanol were also added to the culture media at a concentration of $1 \mu \mathrm{g} \mathrm{mL} \mathrm{m}^{-1}$ each as previously described [38]. Monocultures of anaerobic protists were obtained by transferring individual cells to culture bottles of fresh ciliate mineral medium containing food bacteria (i.e., E. coli strain K-12) from an enriched culture using MM-89 and IM-9B micromanipulators (Narishige, Tokyo, Japan). Each protist was subcultured every 2 or 3 weeks.

\section{Confirmation of protist feeding on GFP-expressing E. coli cells}

Chemically competent E. coli TOP10 (Invitrogen, Waltham, MA, USA) was transformed with vector pUC18-GFP (Nippon Gene, Tokyo, Japan) following the procedure recommended by Invitrogen. E. coli transformants were selected for growth in Luria broth supplemented with ampicillin $100 \mathrm{mg} \mathrm{ml}^{-1}$. GFP-expressing E. coli cells were harvested, washed two times, and resuspended in fresh ciliate mineral medium in a culture bottle. After incubation for $30 \mathrm{~min}$, protists in suspension were removed and checked for ingested bacteria under a fluorescence microscope (BX51, Olympus, Tokyo, Japan).

\section{Tracer experiment using ${ }^{13} \mathrm{C}$-labeled $E$. coli}

The $E$. coli cells were cultured overnight in M9 minimal medium containing $10 \mathrm{mM}$ of fully ${ }^{13} \mathrm{C}$-labeled glucose (Wako Chemicals, Tokyo, Japan) as the sole carbon source at $37{ }^{\circ} \mathrm{C}$ with shaking at $200 \mathrm{rpm}$ [39]. Then, the ${ }^{13} \mathrm{C}$ labeled E. coli cells were harvested, washed two times, and 
resuspended in fresh ciliate mineral medium in a culture bottle (ca. $10^{8}$ cells $\mathrm{mL}^{-1}$ ). The initial bacterial density was $5.0 \times 10^{8}$ cells $\mathrm{mL}^{-1}$. Culture bottles were incubated in triplicate at $25^{\circ} \mathrm{C}$ in the dark. Serum vials containing medium with ${ }^{13} \mathrm{C}$-labeled $E$. coli without protist cells were incubated in parallel as a control.

\section{Feeding experiments of anaerobic protists on various food bacteria}

Propionibacterium acnes (strain UasXy-5) and Trichococcus flocculiformis (strain UasXy-4) were isolated in our laboratory, and Bacteroides luti strain UasXn-3 (JCM 19020) was isolated from anaerobic granular sludge as described previously [40]. Bacteroides graminisolvens (JCM 15093T), Methanospirillum hungatei (JCM10133), Clostridium acetobutylicum (JCM 1419), and Moorella thermoacetica (JCM 9319) were purchased from the Japan Collection of Microorganisms (JCM, RIKEN, Saitama, Japan). Methanobacterium beijingense strain 8-2 (DSM15999) was obtained from the German Resource Centre for Biological Material (DSMZ). In addition, T. flocculiformis, which has a filamentous form with chains of coccoid cells, was separated into single coccus cells by sonication and used as a food bacterium (designated T. flocculiformis-b). Characteristics of each food bacteria used in the protist cultures are shown in Table S1. Microorganisms other than $E$. coli were cultivated anoxically at $37^{\circ} \mathrm{C}$ in anaerobic basal medium as described previously [40] with the following substrate: $10 \mathrm{mM}$ glucose and $0.03 \%$ yeast extract for B. luti, B. graminisolvens, C. acetobutylicum, $M$. thermoacetica, C. acnes, and T. flocculiformis; and $\mathrm{H}_{2} /$ $\mathrm{CO}_{2}(80 / 20, \mathrm{v} / \mathrm{v})$ for $M$. beijingense and $M$. hungatei.

Food bacterial cells were harvested by centrifugation at $8000 \mathrm{rpm}$, washed two times with 0.1 M PBS, and resuspended in fresh ciliate mineral medium in culture bottles. The initial cells concentration was adjusted to $10^{8}$ cells $\mathrm{mL}^{-1}$. Protist cells from monocultures were inoculated into these culture bottles. The experiments were performed more than three times, and each food bacterial culture was subcultured at least three times.

\section{Analytical procedures}

The number of protists was determined by manual counts of the numbers of ciliate cells in a Neubauer chamber (ERMA, Tokyo, Japan) under an IX71 light microscope (Olympus, Tokyo, Japan). To count total bacteria, the samples were filtered on a black polycarbonate membrane after sonication. Then, the membrane was air-dried and mounted with 4,6-diamidino-2phenylindole (DAPI). DAPI-stained bacterial cells from at least three randomly selected visual fields were enumerated.

The growth rate and ingestion rates of each protist were calculated based on time courses of the protists and bacterial numbers during exponential phase growth with the following formula: growth rate $=(\log$ final protist number $\log$ initial protist number)/time interval, ingestion rate $=$ (final bacterial number - initial bacterial number)/((final protist number - initial protist number)/(log final protist number $-\log$ initial protist number))/time interval [41, 42].

Methane was detected using a gas chromatograph equipped with a flame ionization detector (GC-2014, Shimadzu, Kyoto, Japan), and concentrations of ${ }^{13} \mathrm{CO}_{2}$ and ${ }^{13} \mathrm{CH}_{4}$ were determined by GCMS-QP2010SE gas chromatography (Shimadzu, Kyoto, Japan).

After filtration of the samples through $0.2-\mu \mathrm{m}$ pore-size membranes (Advantec, Tokyo, Japan), fermentation products were analyzed by capillary electrophoresis (Agilent 7100 Photal, Otsuka Electronics, Osaka, Japan).

\section{DNA extraction, PCR amplification, and 18S rRNA sequencing}

Genomic DNA was extracted from cultured cells using a FastDNA SPIN Kit for soil (MP Biomedicals, Carlsbad, CA, USA), and DNA concentrations were determined using a NanoDrop Spectrophotometer ND-1000 (Thermo Fisher Scientific, Waltham, MA, USA). Amplification of eukaryotic 18S rRNA was performed using universal eukaryotespecific primer pairs EukA and EukB [43]. Premix Ex Taq Hot Start Version (TaKaRa Bio, Shiga, Japan) was used for PCR under the following conditions: $5 \mathrm{~min}$ at $94^{\circ} \mathrm{C} ; 40$ cycles of $1 \mathrm{~min}$ at $94{ }^{\circ} \mathrm{C}, 1 \mathrm{~min}$ at $58^{\circ} \mathrm{C}$, and $2 \mathrm{~min}$ at $72^{\circ} \mathrm{C}$; and a final 10 -min extension step at $72^{\circ} \mathrm{C}$. PCR products were purified using a QIAquick PCR Purification Kit (QIAGEN, Hilden, Germany), and concentrations were measured using a Qubit dsDNA HS assay kit with a Qubit fluorometer (Thermo Fisher Scientific, MA, USA). After purification, PCR products were sequenced using EukA, Euk-555F [43], and EukB primers and a 3730xl DNA Analyzer (Applied Biosystems, CA, USA).

The nucleic acid sequences obtained were aligned using ClustalW software, and a phylogenetic tree was constructed in MEGA 7 [44] using maximum likelihood (Jones-Taylor-Thornton model), neighbor joining (Poisson model), maximum parsimony (close neighbor interchange in the random-tree search algorithm), and unweighted pair group methods with an arithmetic mean (a maximal composite likelihood model) approaches with B. graminisolvens (GenBank accession number NR_041642) 16 S rRNA gene as an outgroup.

\section{Fluorescence in situ hybridization (FISH)}

Protists used for FISH analyses were cultured with CMV medium without resazurin to minimize the amount of autofluorescence [45]. Protist cells were collected by 
centrifugation $(1000 \times g)$ and fixed with $4 \%$ paraformaldehyde for $1 \mathrm{~h}$ at $4{ }^{\circ} \mathrm{C}$, followed by two washes with $10 \mathrm{mM}$ PBS. Fixed protist cells were embedded in lowmelting agarose (Sigma-Aldrich, Steinheim, Germany) in each well of a 10-well glass slide. After drying, the cells on slides were dehydrated in $50 \%, 80 \%$, and $100 \%$ ethanol for 4, 2, $1 \mathrm{~min}$, respectively and dried again. Then, the fixed cells were hybridized with the oligonucleotide probe Arc915 for methanogenic archaea [46]. The samples were counterstained with DAPI before observation under a fluorescence microscope (BX51, Olympus, Tokyo, Japan).

\section{Nucleotide sequence accession numbers}

Sequence data were deposited in the DDBJ nucleotide sequence database under accession numbers LC497866 to LC497868.

\section{Results}

\section{Isolation of protists}

Three monoxenic cultures of protists were obtained and identified as belonging to the genera Cyclidium, Paracercomonas, and Trichomitus based on morphological features reported previously [13, 47, 48]. Cyclidium sp. YH was a ciliate, and Paracercomonas sp. YH and Trichomitus sp. YH were flagellates. Cyclidium sp. YH and Paracercomonas sp. YH grew with food bacteria alone. In contrast, Trichomitus sp. YH required food bacteria with ergosterol and stigmasterol as co-substrates for growth. The 18S rRNA sequences of Cyclidium sp. YH, Paracercomonas sp. YH, and Trichomitus sp. YH showing 97\% nucleotide identity with Cyclidium porcatum (accession number Z29517), 97\% identity with Paracercomonas anaerobica (AF411272), and 94\% identity with Trichomitus batrachorum (AF124610), respectively (Fig. 1). Although $C$. porcatum was described by morphology-based taxonomy at first [48], molecular phylogeny revealed that the species is not member of the genus Cyclidium and the family Cyclidiidae [45]. Therefore, detailed taxonomic assignment of $C$ porcatum and our isolate Cyclidium sp. YH could be discussed and reclassified in the future. In addition, endosymbiotic methanogens inside of Cyclidium sp. YH cells were confirmed by FISH (Fig. S1) and were not detected in Paracercomonas sp. YH and Trichomitus sp. YH cells.

\section{Confirmation of protist feeding on GFP-expressing E. coli}

Internalization of GFP-expressing $E$. coli by all protist cells was confirmed under a fluorescence microscope (Fig. 2).
Cyclidium sp. YH, the largest protist of the three tested, ingested larger numbers of bacterial cells than Trichomitus sp. YH and Paracercomonas sp. YH. In addition, GFPexpressing E. coli cells localized inside of Cyclidium sp. YH cells, suggesting the formation of food vacuoles. However, E. coli cells were not found localized inside of Trichomitus sp. YH and Paracercomonas sp. YH cells.

\section{Growth characterization and metabolite profiling using ${ }^{13} \mathrm{C}$-labeled $E$. coli}

After cultivation for 10 days, Trichomitus sp. YH and Paracercomonas sp. $\mathrm{YH}$ reached maximum numbers of $1.2 \times 10^{4}$ cells $\mathrm{mL}^{-1}$ and $6.2 \times 10^{4}$ cells $\mathrm{mL}^{-1}$, respectively (Fig. 3). Cyclidium sp. YH grew to a maximum number of $2.2 \times 10^{3}$ cells $\mathrm{mL}^{-1}$ after 18 days of cultivation (Fig. 3 ). The generation time of flagellates was faster than that of the ciliate. Generation times of the ciliate Cyclidium sp. YH ranged from 38.2 to $96.8 \mathrm{~h}$, which was similar to that of other anaerobic ciliates such as Metopus contortus (45-60 h), Metopus palaeformis (35 h), and Plagiopyla frontata $(34 \mathrm{~h})$, but faster than Scuticociliatia strain GW7 $(112.8 \mathrm{~h})$ and slower than $T$. compressum (10-33 h) $[38,45,49,50]$. The generation times of the two isolated flagellates Paracercomonas sp. YH $(27.1-35.5 \mathrm{~h})$ and $T r i-$ chomitus sp. YH $(29.2-46.7 \mathrm{~h})$ were also close to those previously reported for anaerobic flagellates such as Psalteriomonas lanterna $(38 \mathrm{~h})$ [51]. However, the generation times of Trichomitus sp. YH were longer than the minimum generation times of 4-6h for parasite species such as Trichomonas vaginalis in axenic culture [52]. This could be because ingestion of bacterial cells by phagotrophy requires more energy than parasites' absorption of soluble nutrients by osmotrophy under nutrient-rich environments. This phenomenon is observed in mixotrophic algae [53, 54].

After exponential growth, the number of cells of each protist rapidly decreased, probably because accumulation of metabolites such as VFA to toxic levels in each culture [42]. During the exponential growth phase, Cyclidium sp. YH, Trichomitus sp. YH, and Paracercomonas sp. YH ingested $1.8 \times 10^{3}, 1.2 \times 10^{2}$, and $0.6 \times 10^{2}$ cells of food bacteria per protist per hour, respectively.

The metabolite profiles of each protist culture were clearly different (Fig. 4). The major metabolite of Cyclidium sp. YH was acetate, with propionate, butyrate, and valerate detected in smaller amounts. In contrast, acetate and butyrate were the major metabolites of Trichomitus sp. YH, with smaller amounts of propionate found in this culture, and acetate and propionate were the major products of Paracercomonas sp. YH. Lactate, formate, and ethanol were not detected in any of the cultures. Hydrogen was increased in cultures of Trichomitus sp. YH and Paracercomonas sp. YH. However, methane, rather than hydrogen, was detected in cultures of 

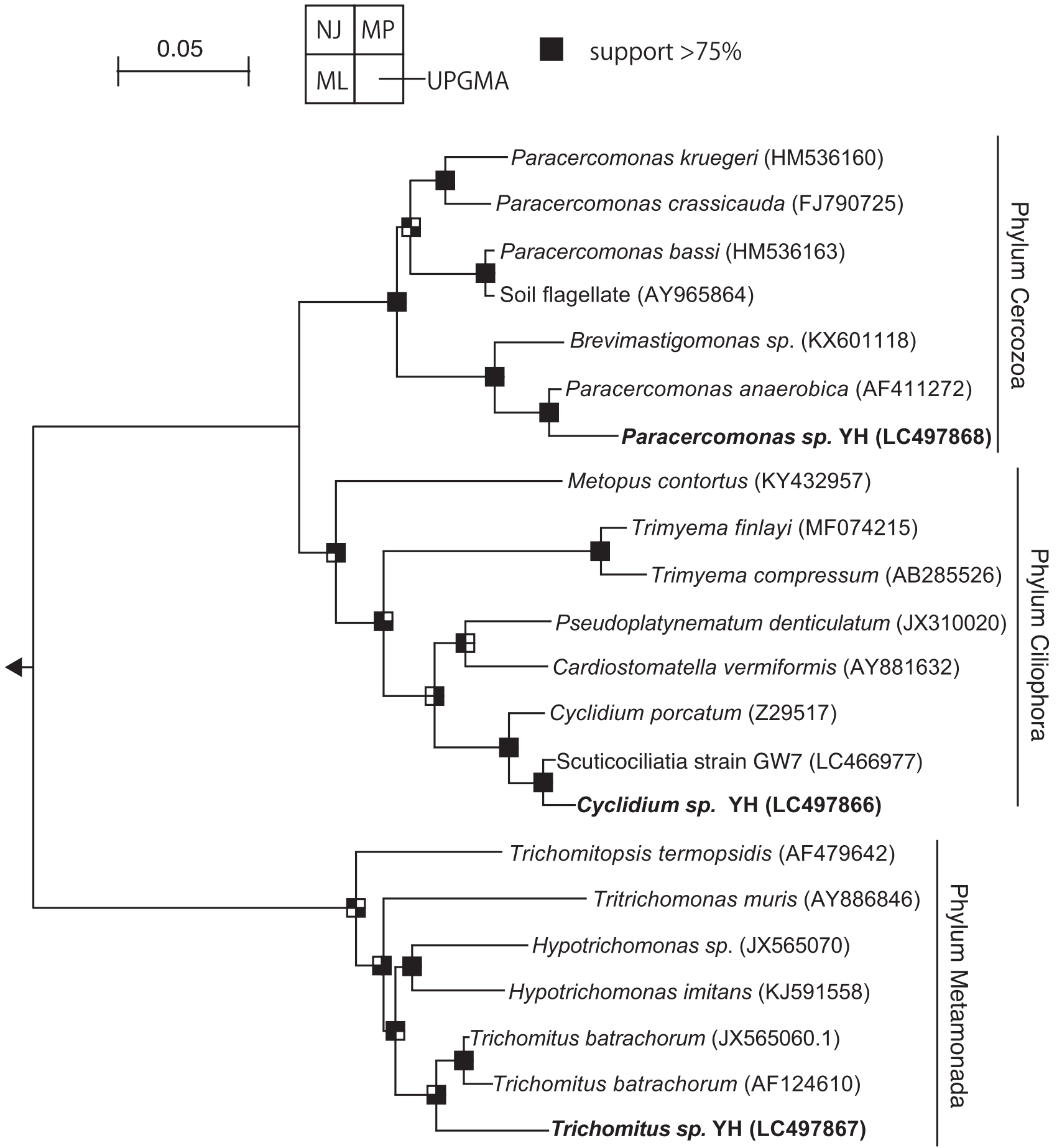

Fig. 1 Neighbor-joining tree showing the phylogenetic affiliation of Cyclidium sp. YH, Paracercomonas sp. YH, and Trichomitus sp. YH isolated in this study. Branching points that support a probability of $>75 \%$ in the bootstrap analyses (based on 1000 replications,

Cyclidium sp. YH that harbored an endosymbiotic methanogen. Cyclidium sp. $\mathrm{YH}$ produced $0.34 \mathrm{pM}$ of $\mathrm{CH}_{4}$ per protist per hour, on average. Trichomitus sp. $\mathrm{YH}$ and Paracercomonas sp. $\mathrm{YH}$ produced hydrogen 0.63 and $0.06 \mathrm{pM}-\mathrm{H}_{2}$ per protist per hour, respectively. Acetate increased in the estimated using the NJ method for the upper-left sector, the MP method for the upper-right sector, the ML method for bottom-left sector, and the UPGMA method for the bottom-right sector) are shown as black squares. The scale bars represent sequence divergence.

cultures of food bacteria without protists, perhaps due to autolysis of $E$. coli cells.

To examine digestion of ${ }^{13} \mathrm{C}$-labeled $E$. coli by protists, ${ }^{13} \mathrm{CO}_{2}$ and ${ }^{13} \mathrm{CH}_{4}$ were measured in the protist cultures (Table 1). After cultivation for 21 days, the percentage of 
Fig. 2 Internalization of GFPexpressing E.coli by each protist. a, b Cyclidium sp. YH;

c, d Paracercomonas sp. YH;

e, f Trichomitus sp. YH. The images were obtained $30 \mathrm{~min}$ after inoculation of GFPexpressing E.coli to protists culture. Panels a, c, and e are bright field. Panels $\mathbf{b}, \mathbf{d}$, and $\mathbf{f}$ are fluorescence field. Panels $\mathbf{a}$ and $\mathbf{b}, \mathbf{c}$ and $\mathbf{d}, \mathbf{e}$ and $\mathbf{f}$ were taken at same location. The scale bar represents $20 \mu \mathrm{m}$.
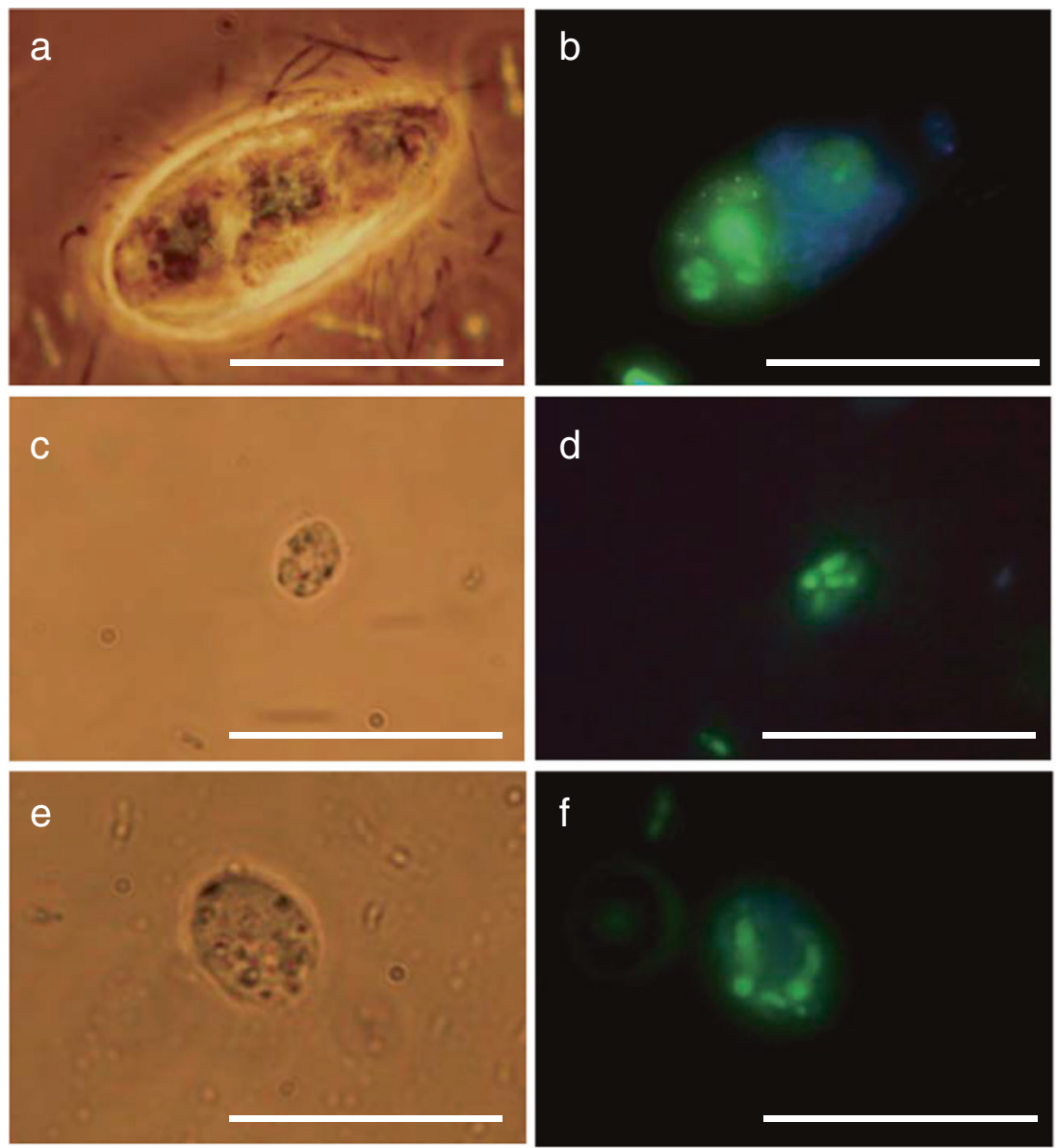
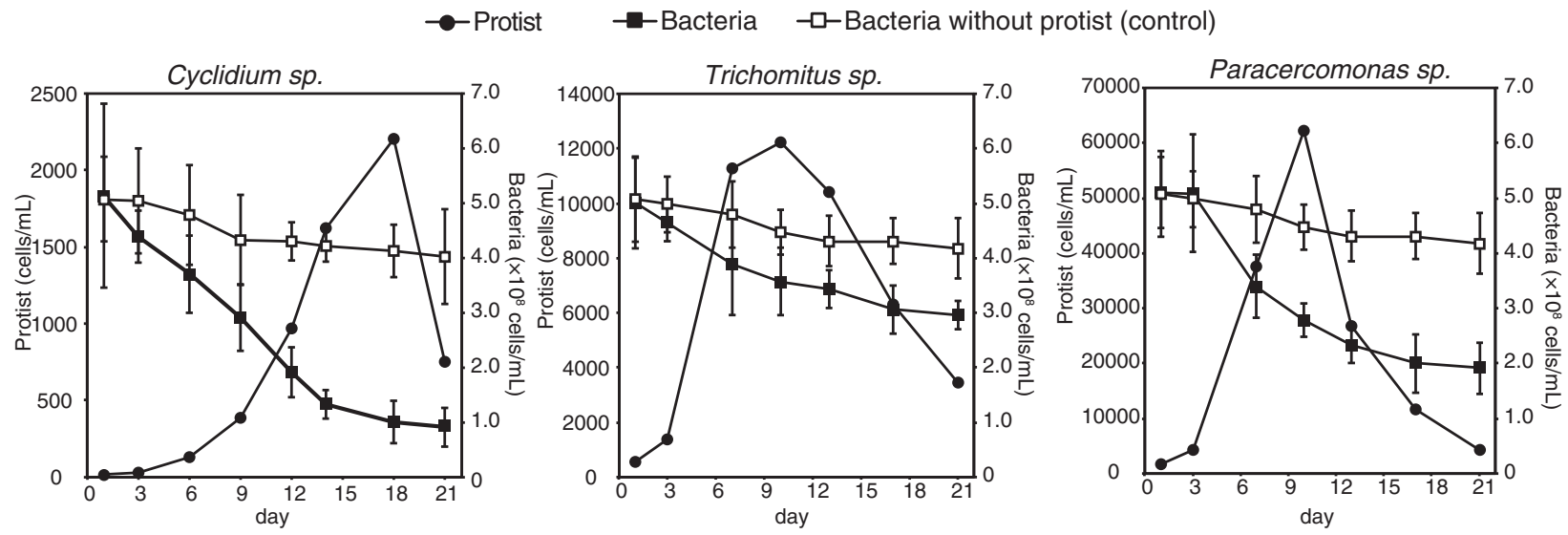

Fig. 3 Growth of each protists with ${ }^{13}$ C-labeled $E$. coli as a food bacteria. Error bars represent the standard deviation.

${ }^{13} \mathrm{CO}_{2}$ increased in all cultures relative to that of the control. The abundance of ${ }^{13} \mathrm{CO}_{2}$ reflected the amount of ${ }^{13} \mathrm{C}$ labeled $E$. coli ingested by each protist. In addition, ${ }^{13} \mathrm{CH}_{4}$ was only detected in the Cyclidium sp. YH cultures, indicating that endosymbiotic methanogens convert $\mathrm{CO}_{2}$ produced by protists into methane gas.

\section{Food selectivity of each anaerobic protists}

Table 2 shows the growth rate and generation times of each protist during the exponential growth phase during culture with various food bacteria. The protists did not grow when 
Fig. 4 Production of fermentation products by each protist with ${ }^{13} \mathrm{C}$-labeled $E$. coli as a food bacteria. Error bars represent the standard deviation.
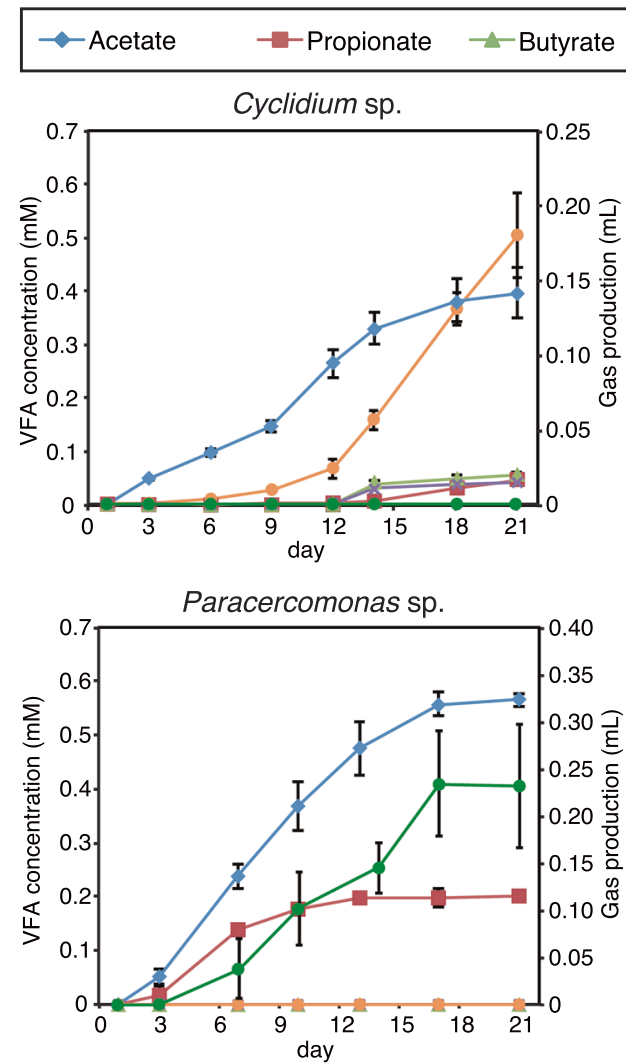

$*$ Valerate $\rightarrow$ Hydrogen $\rightarrow-$ Methane
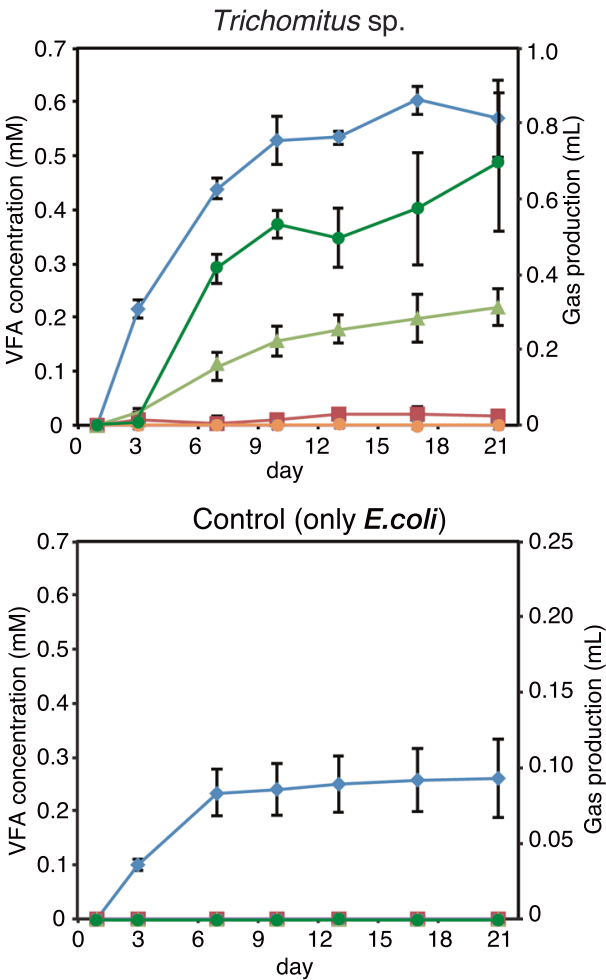

Table 1 Percentage of ${ }^{13} \mathrm{CO}_{2}$ and ${ }^{13} \mathrm{CH}_{4}$ after cultivation.

\begin{tabular}{lll}
\hline Protist & ${ }^{13} \mathrm{CO}_{2}(\%)$ & ${ }^{13} \mathrm{CH}_{4}(\%)$ \\
\hline Cyclidium sp. & $7.0 \pm 0.3$ & $12.9 \pm 2.3$ \\
Trichomitus sp. & $3.9 \pm 0.7$ & - \\
Paracercomonas sp. & $4.6 \pm 0.3$ & - \\
Control $^{\mathrm{a}}$ & $1.7 \pm 0.1$ & - \\
\hline
\end{tabular}

- No detected.

${ }^{a}$ E.coli only (no protists).

Methanobacterium beijingense or Methanospirillum hungatei archaeal cells were used as substrates. Cyclidium sp. YH grew when all tested bacteria except for $T$. flocculiformis were used as substrates. Cyclidium sp. YH, therefore, ingested both Gram-positive and Gram-negative bacteria except for filamentous forms of bacteria. In contrast, Trichomitus sp. YH ingested filamentous T. flocculiformis. Although, Trichomonas sp. YH grew in cultures with either Gram-positive or -negative bacteria, no growth was observed when $P$. acnes or $M$. thermoacetica was used as the food bacterium. Growth of Paracercomonas sp. YH was observed only when they fed on Gram-negative bacteria, namely E. coli, B. luti, and B. graminisolvens. No growth of Paracercomonas sp. YH was observed when Gram-positive bacteria were used as food bacteria. This showed that bacterial cell-wall structure affects Paracercomonas sp. YH food selectivity.

The growth rate and generation times of Cyclidium sp. YH were significantly different depending on the food bacterial species $(p<0.05)$. Among the food bacteria tested, growth rates of Cyclidium sp. YH were higher with E.coli, B. graminisolvens, T. flocculiformis-b, M. thermoacetica, and Clostridium acetobutylicum than with $B$. luti and $P$. acnes. However, the growth rates of Trichomitus sp. YH and Paracercomonas sp. YH did not differ significantly by food bacteria species in present study.

Ingestion rates when the protists were cultured to the exponential growth phase with various food bacteria were highest for Cyclidium sp. YH, followed by Paracercomonas sp. YH and then Trichomitus sp. YH (Fig. 5a). The ingestion rates of Cyclidium sp. YH, Paracercomonas sp. YH, and Trichomitus sp. YH were 1.5-2.7 $\times 10^{3}, 1.3-1.5 \times 10^{2}$, and $0.4-0.6 \times 10^{2}$ cells of food bacteria per protist per hour, respectively. Ingestion rates did not differ by food bacterial species when all bacteria compared could be ingested by a protist.

The volatile fatty acid composition in each protist culture varied markedly according to the food bacterial species present (Fig. 5b). Although, acetate was detected in all cultures, propionate, butyrate, and valerate were not detected in all cases. In cultures of Cyclidium sp. YH fed on 
Table 2 Growth rate $\left(\mathrm{d}^{-1}\right)$ of each protist fed various food bacteria and archaea.

\begin{tabular}{llll}
\hline Food & Cyclidium sp. & Paracercomonas sp. & Trichomitus sp. \\
\hline Gram-negative bacteria & & & \\
$\quad$ E.coli & $0.33 \pm 0.08^{\mathrm{a}}$ & $0.48 \pm 0.07^{\mathrm{a}}$ & $0.59 \pm 0.11^{\mathrm{a}}$ \\
$\quad$ Bacteroides luti & $0.17 \pm 0.02^{\mathrm{b}}$ & $0.51 \pm 0.09^{\mathrm{a}}$ & $0.42 \pm 0.09^{\mathrm{a}}$ \\
$\quad$ Bacteroides graminisolvens & $0.33 \pm 0.08^{\mathrm{a}}$ & $0.61 \pm 0.21^{\mathrm{a}}$ & $0.50 \pm 0.21^{\mathrm{a}}$ \\
Gram-positive bacteria & & & - \\
$\quad \begin{array}{l}\text { Propionibacterium acnes } \\
\text { Trichococcus flocculiformis }\end{array}$ & $0.20 \pm 0.07^{\mathrm{b}}$ & - & $0.61 \pm 0.17^{\mathrm{a}}$ \\
$\quad \begin{array}{l}\text { Trichococcus flocculiformis }-\mathrm{b} \\
\text { Moorella thermoacetica }\end{array}$ & $0.44 \pm 0.05^{\mathrm{a}}$ & - & $0.55 \pm 0.07^{\mathrm{a}}$ \\
$\quad$ Clostridium acetobutylicum & $0.31 \pm 0.03^{\mathrm{a}}$ & - & - \\
Archaea & $0.34 \pm 0.06^{\mathrm{a}}$ & - & $0.38 \pm 0.10^{\mathrm{a}}$ \\
$\quad \begin{array}{l}\text { Methanobacterium beijingense } \\
\text { Methanospirillum hungatei }\end{array}$ & - & - & - \\
\hline
\end{tabular}

Different superscript letters indicate ANOVA grouping with Tukey's test at $95 \%$ confidence.

- not growth. a)

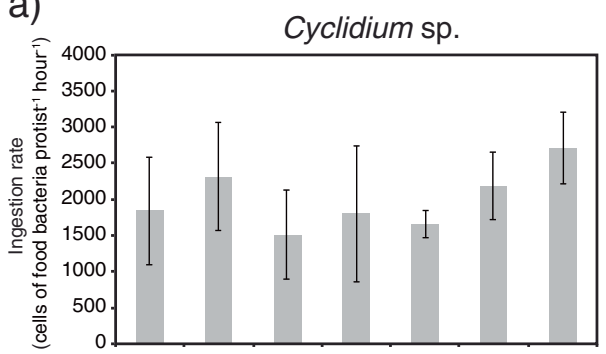

b)

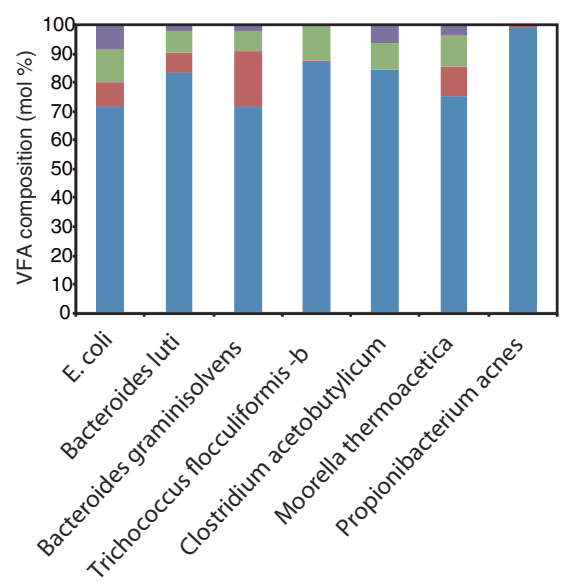

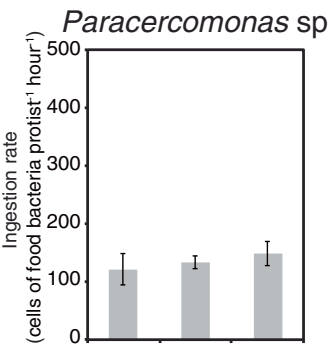

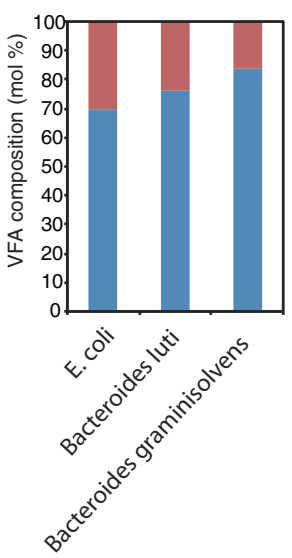

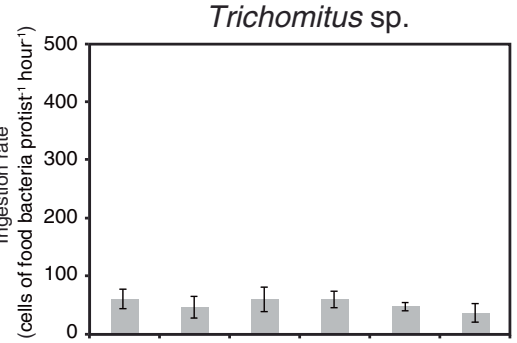

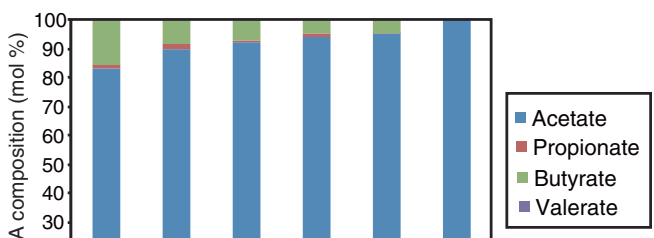

Fig. 5 Ingestion rate (a) and fatty acid compositions (b) of each protists fed various food bacteria. Error bars represent the standard deviation. a Ingestion rates were determined during exponential

B. luti, B. graminisolvens, and M. thermoacetica, acetate, propionate, butyrate, and valerate were detected, similar to that observed when $E$. coli was used as the food bacterium. However, propionate was only slightly detected or not detected when $T$. flocculiformis-b, Clostridium acetobutylicum, and P. acnes were used as food bacteria in growth phase of each protists. b Fatty acid compositions were determined after the protist number reached maximum number.

Cyclidium sp. YH cultures. Furthermore, valerate was not detected when $T$. flocculiformis-b and $P$. acnes were used as food, and butyrate was not detected with $P$. acnes. Although, major products acetate and butyrate and minor product propionate was found in the Trichomitus sp. YH culture, butyrate and propionate were not detected when 
C. acetobutylicum was used as the food bacterium. The major products in all cultures of Paracercomonas sp. YH were acetate and propionate. Regardless of food bacterial species, hydrogen was detected in cultures of Trichomitus sp. YH and Paracercomonas sp. YH, and methane was detected in cultures of Cyclidium sp. YH (data not shown).

\section{Discussion}

Three protist genera isolated in this study belong to the phyla Ciliophora, Cercozoa, and Metamonada, respectively, and these phyla are frequently found in anaerobic environments $[36,55,56]$. Although, most studies have shown that anaerobic protists in these phyla are bacterivorous heterotrophic organisms in various environments $[49,57,58]$, very little is known about their specific roles in anaerobic reactors and natural ecosystems [59]. In anaerobic granular sludge of UASB reactors, particularly, the ecological roles and functions of each anaerobic protist have not been characterized. Therefore, the present study provides important information of these protists' physiological characteristics such as growth rate, generation time, ingestion rate, food selectivity, and metabolites.

Hydrogen and $\mathrm{CO}_{2}$ have been reported to be common metabolites of anaerobic protists [20, 26, 60]. Anaerobic ciliates and trichomonads have unique organelles, hydrogenosomes, instead of mitochondria, in which organic matter is oxidized to volatile fatty acids, hydrogen, and carbon dioxide for ATP synthesis [61]. An anaerobic cercomonad (i.e., Brevimastigomonas motovehiculus) was also found to possess anaerobic mitochondrion-related (hydrogenosome-like) organelles [62]. Hydrogen and ${ }^{13} \mathrm{CO}_{2}$ were detected in the Trichomitus sp. YH and Paracercomonas sp. YH cultures, which suggested that these protists might also possess hydrogenosome-like organelles.

The present study showed that Cyclidium sp. YH directly supplied $\mathrm{CO}_{2}$ and hydrogen to endosymbiotic methanogens because both ${ }^{13} \mathrm{CO}_{2}$ and ${ }^{13} \mathrm{CH}_{4}$ were detected in a tracer experiment using ${ }^{13} \mathrm{C}$-labeled $E$. coli. The presence of hydrogenosomes and methanogens in cells of the genus Cyclidium was observed previously [48 63]. Many researchers have speculated that the relationship between host protist cells and endosymbiotic methanogens is based on syntrophic hydrogen and $\mathrm{CO}_{2}$ transfer; however, this transfer has not been demonstrated previously [25, 27, 64]. This is the first study to show direct evidence of a symbiotic relationship between an anaerobic protist and endosymbiotic methanogens. However, the percentage ${ }^{13} \mathrm{CH}_{4}$ was low (12.9\%), even though ${ }^{13} \mathrm{C}$-labeled E. coli was used as the sole carbon source. This was probably because the endosymbiotic methanogens utilized bicarbonate in the medium and may indicate that the endosymbiotic methanogens used both $\mathrm{CO}_{2}$ produced from hydrogenosomes and dissolved $\mathrm{CO}_{2}$ from outside of host protist cells. Thus, endosymbiotic methanogens can contribute to the maintenance of hydrogen concentrations at very low levels by scavenging exterior hydrogen or that produced from hydrolysis.

Feeding experiments in this study showed that the food selectivity of the protists were affected by the cell shape and cell-wall structure of food bacteria. Effects of bacterial cell shape on protist predation are well known; size-selective predation by protists exists, and filamentous bacteria are morphologically resistant to predation $[65,66]$. Although, Trichomitus sp. YH can take up both Gram-positive and -negative bacteria, $P$. acnes and M. thermoacetica did not support growth, suggesting that cell shape and cell-wall structure of food bacteria were not the only factors associated with the growth of Trichomitus sp. YH. Yamada et al. [20] also reported that food selectivity of the anaerobic ciliate $T$. compressum depends on the digestibility of food bacteria rather than on differences in general cell-wall structure.

The feeding experiment with Paracercomonas sp. YH revealed, however, that the cell-wall structure of food bacteria does influence their food selectivity. Paracercomonas sp. YH can grow only on Gram-negative bacteria. This might indicate that this protist does not have enzymes to digest the thick peptidoglycan layer of Gram-positive bacteria. None of the three protists grew when fed archaea. This also could be related to the indigestibility of their cell walls. Archaea possess cell walls like sheaths and pseudomurein as a cell-wall component, which differs from the walls of bacterial cells. Digestive enzymes in protists should be examined in future studies.

Previous studies have suggested that food bacterial species influence fermentation patterns and growth rates of anaerobic protists such as $T$. compressum [20,38, 64]. We also observed that the metabolites from and growth rates of Cyclidium sp. YH changed depending on food bacteria. The metabolite profiles of Trichomitus sp. YH also changed depending on food bacterial species, although its growth rates were not affected. Thus, our results support the idea that the metabolisms of anaerobic protists are affected by food bacterial species, and that anaerobic protists can supply various metabolites to environments based on the bacterial species ingested.

The growth rates of Cyclidium sp. YH were affected by food bacteria, but its ingestion rates did not differ significantly based on food bacterial species. This suggests that the amount of nutrients obtained varies by food bacterium. To compare the relationship between each food bacterium and protist growth, we estimated the cell number and 
volume required for protist growth (Fig. S2). Significant differences were observed in the number and volume of cells need for Cyclidium sp. YH growth. Significantly more food bacterial cells or cell volume was needed for growth of Cyclidium sp. YH with $B$. luti and $P$. acens than T. flocculiformis-b. Therefore, it is likely that $T$. flocculiformis-b cells were better substrates for Cyclidium sp. YH than B. luti and $P$. acens for growth and a source of energy. This is consistent of cell yields (increased number of protist cells/ number of ingested bacterial cells) for Cyclidium sp. YH. When T. flocculiformis-b used as food bacteria the cell yield was $1.1 \times 10^{-5} \pm 3.8 \times 10^{-6}$, this was significantly higher than that of $B$. luti $\left(2.8 \times 10^{-6} \pm 7.0 \times 10^{-7}\right)$ or $P$. acens $\left(3.1 \times 10^{-6} \pm 3.1 \times 10^{-7}\right) \quad(p<0.05)$. A previous study showed that use of specific bacteria as a substrate stimulated protist growth and maximum cell number [67, 68]. In addition, protists such as Trimyema sp., Paramecium sp., and $P$. shumwayae are known to need sterol and fatty acids as a growth factor $[38,69,70]$. Moreover, $T$. compressum cell yields were reported to change based on bacterial cell qualities like carbohydrate and protein contents [50]. Although the metabolite composition of Cyclidium sp. YH with each food bacterium had no apparent association with high or low growth rates, our results suggest that differences in the nutrients contained in food bacteria can affect protist growth. This could be occurring in other protists species as well, because the metabolite compositions of Trichomitus sp. YH and Paraceromonas sp. YH were also altered depending on the food bacteria consumed.

The rate of bacterial ingestion of Cyclidium sp. YH was the fastest of the three. Cyclidium sp. YH, which is a ciliate, was larger than the two other isolates, which are flagellates, suggesting that the difference in ingestion rates is associated with cell size. Comparing the ingestion rates of 12 aerobic and 6 anaerobic protists that similar to our experimental conditions (Table S2 and Fig. 6), it seems to be logarithmically proportional to the cell volume regardless of either anaerobic or aerobic species. Our data and other anaerobic protist are in the same trends. The slope of regression line is 0.75 (Fig. 6), which is close to slope of respiration rates of aerobic protists against cell volume [71]. Thus, we might be roughly estimate an ingestion rate based on protists cell size. Most ciliates have a large cell size and can consume more prokaryotic cells than flagellates [11, 72, 73]. In particular, members of the genus Cyclidium have shown great efficiency in removing organic matter and can contribute to sludge reduction and treatment by predation in anaerobic treatment processes $[23,36]$.

The food selectivity of Cyclidium sp. proved the previous our prediction that the ciliate in UASB reactor was selectively ingesting the rod or coccus-shaped bacteria in outer layer of granular sludge [1]. In UASB reactor, number of ciliates were

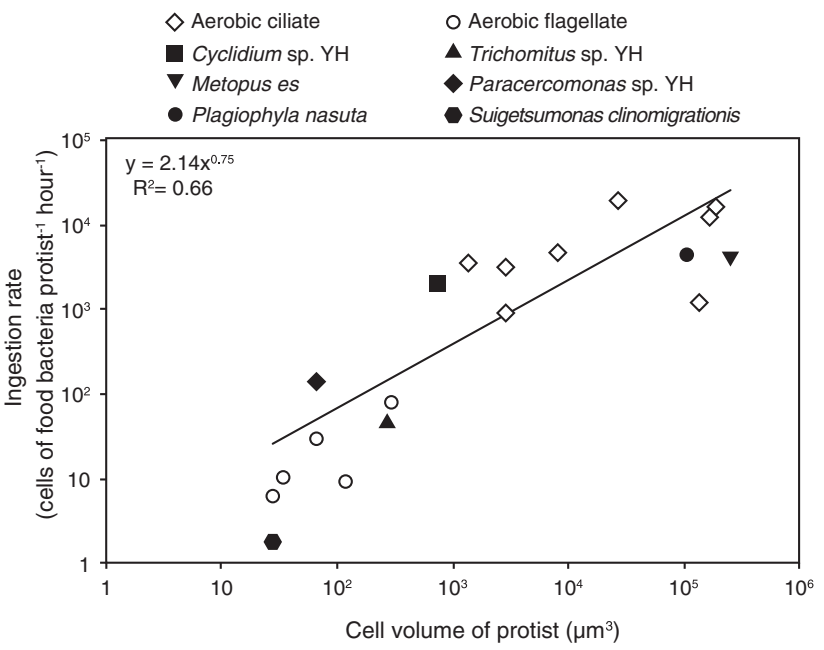

Fig. 6 Ingestion rate of various protists under high prey concentration $\left(10^{7}\right.$ cells $\left.\mathrm{mL}^{-1} \leq\right)$ against cell volume. The plotted data are obtained this study and from the references listed in Table S2.

ranged $10^{2}$ to $10^{3}$ cells $\mathrm{mL}^{-1}$ [1] and combining the ingestion rate, it is assumed that the maximum contribution of Cyclidium sp. for control of bacterial populations is estimated up to $5.8 \times 10^{7}$ cells of bacteria $\mathrm{mL}^{-1}$ day $^{-1}$. Although this ingestion rate is $<0.1 \%$ day $^{-1}$ of prokaryotes (both bacteria and archaea) of granular sludge (more than $10^{12}$ cells $\mathrm{mL}^{-1}$ ), it is increased $1.2 \% \mathrm{day}^{-1}$ if limited to bacteria located in the outer layer of granular sludge that could be ingested by protist (ca. $5 \times 10^{9}$ cells $\mathrm{mL}^{-1}$ ) [74]. This bacteria turnover rate is compatible with prokaryotes turnover rate by grazing effect in marine and lake $\left(0.83-49.0 \% \mathrm{day}^{-1}\right)$ [75]. This nonnegligible bacteria turnover rate by ciliate ingestion could be a reasons for proliferation of syntrophic microorganism in UASB reactor and higher methane concentration though the COD removal is same [1].

In addition, flagellates reach higher cell numbers than ciliates [76], as we found in this study. In natural environments such as lake and marine, flagellates numbers are ranged $10^{4}-10^{6}$ cells $\mathrm{mL}^{-1}$, which is $10-100$ times higher than ciliates [77 78]. Thus, total contributions of Trichomitus sp. and Paracercomonas sp. to control of bacterial populations could be the same to Cyclidium sp. in actual environments. In particular, Trichomitus sp. YH can ingest filamentous bacteria, which is important findings because ingestion of filamentous bacteria by anaerobic protist was not reported previously, they might be key factor to prevent bulking caused by filamentous bacteria in UASB reactor [79]. However, limited information about their effects is available although food selectivity of protists expects to change prokaryotes community. These relationships between protists and bacterial community in actual environment need to be examined in future studies. 


\section{Conclusion}

In the present study, three bacterivorous protists representing different phyla from a UASB reactor were isolated and provide quantitative data for ingestion rate, specific food selectivity, and metabolites. In addition, a tracer experiment using ${ }^{13} \mathrm{C}$-labeled $E$. coli cells showed that Cyclidium sp. $\mathrm{YH}$ directly supplied $\mathrm{CO}_{2}$ and hydrogen to endosymbiotic methanogens. The information provide important insights into the ecological roles of these protists in anaerobic ecosystems and will help to estimate an actual contribution of protozoan community in anaerobic reactor.

Acknowledgements This research was supported financially by Grants-in-Aid for Scientific Research from the Japan Society for the Promotion of Science. Grant Numbers 19H01163, 17J09970, and 16H02371. Also supported by Nagaoka University of Technology Presidential Research Grant.

\section{Compliance with ethical standards}

Conflict of interest The authors declare that they have no conflict of interest.

Publisher's note Springer Nature remains neutral with regard to jurisdictional claims in published maps and institutional affiliations.

\section{References}

1. Hirakata Y, Oshiki M, Kuroda K, Hatamoto M, Kubota K, Yamaguchi T, et al. Effects of predation by protists on prokaryotic community function, structure, and diversity in anaerobic granular sludge. Microbes Environ. 2016;31:279-87.

2. Holmes DE, Giloteaux L, Orellana R, Williams KH, Robbins MJ, Lovley DR. Methane production from protozoan endosymbionts following stimulation of microbial metabolism within subsurface sediments. Front Microbiol. 2014;5:366.

3. Biagini GA, Finlay BJ, Lloyd D. Protozoan stimulation of anaerobic microbial activity: enhancement of the rate of terminal decomposition of organic matter. FEMS Microbiol Ecol. 1998;27: $1-8$.

4. Massana R, Pedrós-Alió C. Role of anaerobic ciliates in planktonic food webs: abundance, feeding, and impact on bacteria in the field. Appl Environ Microbiol. 1994;60:1325-34.

5. Saccà A, Borrego CM, Renda R, Triadó-Margarit X, Bruni V, Guglielmo L. Predation impact of ciliated and flagellated protozoa during a summer bloom of brown sulfur bacteria in a meromictic coastal lake. FEMS Microbiol ecol. 2009;70:42-53.

6. Santra A, Karim SA. Influence of ciliate protozoa on biochemical changes and hydrolytic enzyme profile in the rumen ecosystem. $\mathrm{J}$ Appl Microbiol. 2002;92:801-11.

7. Jousset A. Ecological and evolutive implications of bacterial defences against predators. Environ Microbiol. 2012;14:1830-43.

8. Martinez-Garcia M, Brazel D, Poulton NJ, Swan BK, Gomez ML, Masland D, et al. Unveiling in situ interactions between marine protists and bacteria through single cell sequencing. ISME J. 2012;6:703.

9. Šimek K, Chrzanowski TH. Direct and indirect evidence of sizeselective grazing on pelagic bacteria by freshwater nanoflagellates. Appl Environ Microbiol. 1992;58:3715-20.
10. Pernthaler J. Predation on prokaryotes in the water column and its ecological implications. Nat Rev Microbiol. 2005;3:537-46.

11. Gonzalez JM, Sherr EB, Sherr BF. Size-selective grazing on bacteria by natural assemblages of estuarine flagellates and ciliates. Appl Environ Microbiol. 1990;56:583-9.

12. Wu QL, Boenigk J, Hahn MW. Successful predation of filamentous bacteria by a nanoflagellate challenges current models of flagellate bacterivory. Appl Environ Microbiol. 2004;70:332-9.

13. Bass D, Howe AT, Mylnikov AP, Vickerman K, Chao EE, Smallbone JE, et al. Phylogeny and classification of Cercomonadida (protozoa, Cercozoa): Cercomonas, Eocercomonas, Paracercomonas, and Cavernomonas gen. nov. Protist. 2009;160:483-521.

14. Finlay BJ, Fenchel T. An anaerobic protozoon, with symbiotic methanogens, living in municipal landfill material. FEMS Microbiol Lett. 1991;85:169-79.

15. Gill EE, Diaz-Triviño $S$, Barberà MJ, Silberman JD, Stechmann A, Gaston D, et al. Novel mitochondrion-related organelles in the anaerobic amoeba Mastigamoeba balamuthi. Mol Microbiol. 2007;66:1306-20.

16. Yabuki A, Nakayama T, Yubuki N, Hashimoto T, ISHIDA KI, Inagaki Y. Tsukubamonas globosa n. gen., n. sp., a novel excavate flagellate possibly holding a key for the early evolution in "Discoba”. J Eukaryot Microbiol. 2011;58:319-31.

17. Murase J, Noll M, Frenzel P. Impact of protists on the activity and structure of the bacterial community in a rice field soil. Appl Environ Microbiol. 2006;72:5436-44.

18. Ohene-Adjei S, Teather RM, Ivan M, Forster RJ. Postinoculation protozoan establishment and association patterns of methanogenic archaea in the ovine rumen. Appl Environ Microbiol. 2007;73:4609-18.

19. Schulz S, Wagener S, Pfennig N. Utilization of various chemotrophic and phototrophic bacteria as food by the anaerobic ciliate Trimyema compressum. Eur J Protistol. 1990;26:122-31.

20. Yamada K, Kamagata Y, Nakamura K, Inamori Y, Nakamura I. Selectivity of food bacteria for the growth of anaerobic ciliate Trimyema compressum. Arch Microbiol. 1994;161:229-33.

21. Matsubayashi M, Shimada Y, Li YY, Harada H, Kubota K. Phylogenetic diversity and in situ detection of eukaryotes in anaerobic sludge digesters. PloS ONE. 2017;12:e0172888.

22. Simon M, López-García P, Deschamps P, Moreira D, Restoux G, Bertolino $\mathrm{P}$, et al. Marked seasonality and high spatial variability of protist communities in shallow freshwater systems. ISME J. 2015;9:1941.

23. Prabhakaran P, Bhasi A, Ali S, Narayanan N, Balakrishnan MV, Bhaskaran K. Community dynamics and significance of anaerobic protozoa during biomethanation of lignocellulosic waste. Renew Energy. 2016;98:148-52.

24. Priya M, Haridas A, Manilal VB. Involvement of protozoa in anaerobic wastewater treatment process. Water Res. 2007;41:4639-45.

25. Shinzato N, Watanabe I, Meng XY, Sekiguchi Y, Tamaki H, Matsui $\mathrm{T}$, et al. Phylogenetic analysis and fluorescence in situ hybridization detection of archaeal and bacterial endosymbionts in the anaerobic ciliate Trimyema compressum. Micro Ecol. 2007;54:627-36.

26. Zimorski V, Mentel M, Tielens AG, Martin WF. Energy metabolism in anaerobic eukaryotes and Earth's late oxygenation. Free Radic Biol Med. 2019;140:279-94.

27. Hirakata Y, Oshiki M, Kuroda K, Hatamoto M, Kubota K, Yamaguchi $\mathrm{T}$, et al. Identification and detection of prokaryotic symbionts in the ciliate Metopus from anaerobic granular sludge. Microbes Environ. 2015;30:335-8.

28. van Bruggen JJ, Stumm CK, Vogels GD. Symbiosis of methanogenic bacteria and sapropelic protozoa. Arch Microbiol. 1983;136:89-95. 
29. Gast RJ, Sanders RW, Caron DA. Ecological strategies of protists and their symbiotic relationships with prokaryotic microbes. Trends Microbiol. 2009;17:563-9.

30. Hackstein JH, Vogels GD. Endosymbiotic interactions in anaerobic protozoa. Antonie Van Leeuwenhoek. 1997;71:151-8.

31. Shinzato N, Takeshita K, Kamagata Y. (2018). Methanogenic and bacterial endosymbionts of free-living anaerobic ciliates. In: Hackstein JHP, editor. (Endo)symbiotic methanogenic archaea, Microbiology monographs. vol 19. Berlin Heidelberg: SpringerVerlag; 2018. p. 37-53.

32. Teh YA, Dubinsky EA, Silver WL, Carlson CM. Suppression of methanogenesis by dissimilatory $\mathrm{Fe}$ (III)-reducing bacteria in tropical rain forest soils: Implications for ecosystem methane flux. Glob Chang Biol. 2008;14:413-22.

33. Wintsche B, Jehmlich N, Popp D, Harms H, Kleinsteuber S. Metabolic adaptation of methanogens in anaerobic digesters upon trace element limitation. Front Microbiol. 2018;9:405.

34. Saunders EC, de Souza DP, Chambers JM, Ng M, Pyke J, McConville MJ. Use of ${ }^{13} \mathrm{C}$ stable isotope labelling for pathway and metabolic flux analysis in Leishmania parasites. Methods Mol Biol. 2015;1201:281-96.

35. Creek DJ, Mazet M, Achcar F, Anderson J, Kim DH, Kamour R, et al. Probing the metabolic network in bloodstream-form Trypanosoma brucei using untargeted metabolomics with stable isotope labelled glucose. PLoS Pathog. 2015;11:e1004689.

36. Hirakata Y, Hatamoto M, Oshiki M, Watari T, Kuroda K, Araki $\mathrm{N}$, et al. Temporal variation of eukaryotic community structures in UASB reactor treating domestic sewage as revealed by $18 \mathrm{~S}$ rRNA gene sequencing. Sci Rep. 2019;9:1-11.

37. Sambrook J, Russell DW. Molecular cloning: a laboratory manual. 3rd ed. New York: Cold Spring Harbor Laboratory Press; 2001.

38. Wagener S, Pfennig N. Monoxenic culture of the anaerobic ciliate Trimyema compressum Lackey. Arch Microbiol. 1987;149:4-11.

39. Haig SJ, Schirmer M, D'amore R, Gibbs J, Davies RL, Collins G, et al. Stable-isotope probing and metagenomics reveal predation by protozoa drives E. coli removal in slow sand filters. ISME J. 2015;9:797.

40. Hatamoto M, Kaneshige M, Nakamura A, Yamaguchi T. Bacteroides luti sp. nov., an anaerobic, cellulolytic and xylanolytic bacterium isolated from methanogenic sludge. Int J Syst Evol Microbiol. 2014;64:1770-4.

41. Kujawinski EB, Farrington JW, Moffett JW. Evidence for grazing-mediated production of dissolved surface-active material by marine protists. Mar Chem. 2002;77:133-42.

42. Narayanan N, Priya M, Haridas A, Manilal VB. Isolation and culturing of a most common anaerobic ciliate, Metopus sp. Anaerobe. 2007;13:14-20.

43. Miyaoka Y, Hatamoto M, Yamaguchi T, Syutsubo K. Eukaryotic community shift in response to organic loading rate of an aerobic trickling filter (down-flow hanging sponge reactor) treating domestic sewage. Micro Ecol. 2017;73:801-14.

44. Kumar S, Stecher G, Tamura K. MEGA7: molecular evolutionary genetics analysis version 7.0 for bigger datasets. Mol Biol Evol. 2016;33:1870-4.

45. Takeshita K, Yamada T, Kawahara Y, Narihiro T, Ito M, Kamagata Y, et al. Tripartite symbiosis of an Anaerobic Scuticociliate with two hydrogenosome-associated Endosymbionts, a holospora-related Alphaproteobacterium and a Methanogenic Archaeon. Appl Environ Microbiol. 2019;24:e00854-19.

46. Raskin L, Poulsen LK, Noguera DR, Rittmann BE, Stahl DA. Quantification of methanogenic groups in anaerobic biological reactors by oligonucleotide probe hybridization. Appl Environ Microbiol. 1994;60:1241-8.
47. Krishnamurthy R. The morphology of Trichomitus batrachorum (Perty, 1852) Honigberg, 1963 from two squamate reptiles, Eryx johni and Varanus sp. Curr Sci. 1967;36:672-4.

48. Clarke KJ, Finlay BJ, Esteban G, Guhl BE, Embley TM. Cyclidium porcatum n. sp.: a free-living anaerobic scuticociliate containing a stable complex of hydrogenosomes, eubacteria and archaeobacteria. Eur J Protistol. 1993;29:262-70.

49. Fenchel T, Finlay BJ. Anaerobic free-living protozoa: growth efficiencies and the structure of anaerobic communities. FEMS Microbiol Lett. 1990;74:269-75.

50. Holler S, Gälle A, Pfennig N. Degradation of food compounds and growth response on different food quality by the anaerobic ciliate Trimyema compressum. Arch Microbiol. 1994;161:94-8.

51. Broers CA, Meijers HH, Symens JC, Stumm CK, Vogels GD, Brugerolle G. Symbiotic association of Psalteriomonas vulgaris $n$. spec. with Methanobacterium formicicum. Eur J Protistol. 1993;29:98-105.

52. Nix DE, Tyrrell R, Müller M. Pharmacodynamics of metronidazole determined by a time-kill assay for Trichomonas vaginalis. Antimicrob Agents Chemother. 1995;39:1848-52.

53. Mulholland MR, Morse R, Egerton T, Bernhardt PW, Filippino KC. Blooms of dinoflagellate mixotrophs in a lower Chesapeake Bay tributary: carbon and nitrogen uptake over diurnal, seasonal, and interannual timescales. Estuar Coast. 2018;41:1744-65.

54. Rengefors K, Pålsson C, Hansson LA, Heiberg L. Cell lysis of competitors and osmotrophy enhance growth of the bloomforming alga Gonyostomum semen. Aquat Micro Ecol. 2008;51:87-96.

55. Matsunaga K, Kubota K, Harada H. Molecular diversity of eukaryotes in municipal wastewater treatment processes as revealed by 18S rRNA gene analysis. Microbe Environ. 2014;29:401-7.

56. Triadó-Margarit X, Casamayor EO. High protists diversity in the plankton of sulfurous lakes and lagoons examined by $18 \mathrm{~s}$ rRNA gene sequence analyses. Environ Microbiol Rep. 2015;7:908-17.

57. O'Kelly CJ, Farmer MA, Nerad TA. Ultrastructure of Trimastix pyriformis (Klebs) Bernard et al.: similarities of Trimastix species with retortamonad and jakobid flagellates. Protist. 1999;150:149-62.

58. Takishita K, Tsuchiya M, Kawato M, Oguri K, Kitazato H, Maruyama T. Genetic diversity of microbial eukaryotes in anoxic sediment of the saline meromictic lake Namako-ike (Japan): on the detection of anaerobic or anoxic-tolerant lineages of eukaryotes. Protist. 2007;158:51-64.

59. Bayané A, Guiot SR. Animal digestive strategies versus anaerobic digestion bioprocesses for biogas production from lignocellulosic biomass. Rev Environ Sci Biotechnol. 2011;10:43-62.

60. Müller M. Energy metabolism. Part I: anaerobic protozoa. In: J Marr, editor. Molecular medical parasitology. London: Academic Press; 2003. p. 125-39.

61. Müller M. The hydrogenosome. Microbiology. 1993;139: 2879-89.

62. Gawryluk RM, Kamikawa R, Stairs CW, Silberman JD, Brown MW, Roger AJ. The earliest stages of mitochondrial adaptation to low oxygen revealed in a novel rhizarian. Curr Biol. 2016;26: 2729-38.

63. Esteban G, Finlay BJ, Embley TM. New species double the diversity of anaerobic ciliates in a Spanish lake. FEMS Microbiol Lett. 1993;109:93-9.

64. Goosen NK, Van der Drift C, Stumm CK, Vogels GD. End products of metabolism in the anaerobic ciliate Trimyema compressum. FEMS Microbiol Lett. 1990;69:171-6.

65. Hahn MW, Moore ERB, Höfle MG. Bacterial filament formation, a defense mechanism against flagellate grazing, is growth rate controlled in bacteria of different phyla. Appl Environ Microbiol. 1999;65:25-35. 
66. Corno G, Jürgens K. Direct and indirect effects of protist predation on population size structure of a bacterial strain with high phenotypic plasticity. Appl Environ Microbiol. 2006;72:78-86.

67. Caron DA, Lim EL, Miceli G, Waterbur JB, Valois FW. Grazing and utilization of chroococcoid cyanobacteria and heterotrophic bacteria by protozoa in laboratory cultures and a coastal plankton community. Mar Ecol Prog Ser. 1991;76:205-17.

68. Odelson DA, Breznak JA. Nutrition and growth characteristics of Trichomitopsis termopsidis, a cellulolytic protozoan from termites. Appl Environ Microbiol. 1985;49:614-21.

69. Skelton HM, Burkholder JM, Parrow MW. Axenic cultivation of the heterotrophic dinoflagellate Pfiesteria shumwayae and observations on feeding behavior ${ }^{1}$. J Phycol. 2008;44:1614-24.

70. Soldo AT, Van Wagtendonk WJ. An analysis of the nutritional requirements for fatty acids of Paramecium aurelia. J Protozool. 1967;14:596-600.

71. Fenchel T, Finlay BJ. Respiration rates in heterotrophic, freeliving protozoa. Micro Ecol. 1983;9:99-122.

72. Meira BR, Lansac-Toha FM, Segovia BT, Buosi PRB, LansacTôha FA, Velho LFM. The importance of herbivory by protists in lakes of a tropical floodplain system. Aquat Ecol. 2018;52:193-210.

73. Epstein SS, Shiaris MP. Size-selective grazing of coastal bacterioplankton by natural assemblages of pigmented flagellates, colorless flagellates, and ciliates. Micro Ecol. 1992;23:211-25.
74. Wu WM, Jain MK, De Macario EC, Thiele JH, Zeikus JG. Microbial composition and characterization of prevalent methanogens and acetogens isolated from syntrophic methanogenic granules. Appl Microbiol Biot. 1992;38:282-90.

75. Medina LE, Taylor CD, Pachiadaki MG, Henríquez-Castillo C, Ulloa O, Edgcomb VP. A review of protist grazing below the photic zone emphasizing studies of oxygen-depleted water columns and recent applications of in situ approaches. Front Mar Sci. 2017;4:105.

76. Gasol JM. Benthic flagellates and ciliates in fine freshwater sediments: calibration of a live counting procedure and estimation of their abundances. Microb Ecol. 1993;25:247-62.

77. Sonntag B, Posch T, Klammer S, Teubner K, Psenner R. Phagotrophic ciliates and flagellates in an oligotrophic, deep, alpine lake: contrasting variability with seasons and depths. Aquat Microb Ecol. 2006;43:193-207.

78. Baltar F, Palovaara J, Unrein F, Catala P, Horňák K, Šimek K et al. Marine bacterial community structure resilience to changes in protist predation under phytoplankton bloom conditions. ISME J. 2016;10:568-81.

79. Yamada T, Yamauchi T, Shiraishi K, Hugenholtz P, Ohashi A, Harada $H$, et al. Characterization of filamentous bacteria, belonging to candidate phylum KSB3, that are associated with bulking in methanogenic granular sludges. ISME J. 2007;1: 246-55. 